\title{
The achievement of the country's sustainable development in the conditions of global threats
}

\author{
Nataliia Stukalo ${ }^{1}$, Maryna Lytvyn ${ }^{2 *}$, Yuriy Petrushenko ${ }^{3}$, and Yuliia Omelchenko ${ }^{3}$ \\ ${ }^{1}$ National Agency for Higher Education Quality Assurance, Kyiv, 01001, Ukraine \\ ${ }^{2}$ Department of Economic Theory and International Economic Relations, Dnipro University of \\ Technology, Dnipro, 49027, Ukraine \\ ${ }^{3}$ Department of International Economic Relations, Sumy State University, Sumy, 40007, Ukraine
}

\begin{abstract}
The 2030 Agenda for Sustainable Development stipulates the need for economical use of natural resources and the introduction of green technologies to ensure the harmonious reconciliation of economic, social, and environmental development. However, the problems associated with the definition of the country's sustainable development in conditions of global threats are far from being solved and require further theoretical efforts. So,the purpose of the article is to form a methodological approach to define the country's sustainable development in conditions of global threats. The methods used in this study are the comparative and statistical analysis, the systematic approach - in creating the mechanism of ensuring the sustainable development of the world in conditions of global challenges. The analysis results show that the methodological approach allows assessing the country's sustainable development considering global threats, which, in turn, policy adjustments to strengthen sustainable development in global crises. This study concludes that globalization's process causes various changes; the positive or negative vector of these changes largely depends on the level of sustainable development of the country and the country's position in the world economy. The higher the country's sustainable development indicators, the more positive effects of globalization the state receives.
\end{abstract}

\section{Introduction}

Today, the research of sustainable development global threats is especially relevant in the world economy and international economic relations. Globalization has become the primary tool for overcoming uneven development and environmental problems to Global Sustainable Development Goals. The 2030 Agenda for Sustainable Development envisages the need for economic use of resources and the introduction of green technologies to ensure the harmonious coordination of socially oriented environmentally sound economic development. Although the Agenda for Sustainable Development involves global resources, economic and

\footnotetext{
* Corresponding author:lytvyn.m.v@nmu.one
} 
social development is a priority for each country, as expressed in national development policies and strategies.

The foreign scientists studied the theoretical and practical aspects of achieving sustainable development. Peculiarities of sustainable development, ensuring in countries of the modern world in the context of globalization are the debatable issue among authors and experts. Z. Burykhas explored the methodological aspects of sustainable development economics in the article «Theoretical and methodological basis of sustainable development economics» [1]. N. Stukalo, I. Steblianko, A. Simakhova, V. Doroshkevych have explored aspects of security and sustainability in the article "Trends in economic and social security at national and European level: interrelationships, threats, and opportunities" [2]. I. Zvarychand I. Ivashchuk have investigated the aspects of inclusive growth vectors in the global inclusive circular economy's functioning [3].

M.Hirt at al.have investigated the strategic crisis-action plan guides responses to a crisis's unfolding stages, the scenarios for the economic impact of the COVID-19 crisis in the article «Getting ahead of the next stage of the coronavirus crisis» [4]. L. Jackson has explored the ten worrying trends of the global economy in the article «Ten worrying trends of the global economy [5]. Here are the biggest economic challenges we face over the next ten years». V. Gaspar et al. have investigated the financial instruments to achieve global goals of sustainable development [6]. M. Zgurovsky's research [7-8] devoted to the analysis of sustainable development of different countries of the world in the conditions of global challenges and threats. The world data center for geoinformatics and sustainable development [9] annually analyzes all countries' sustainable development. The analysis results are published in the form of research, which, in addition to the methodological aspects of analysis, contains detailed portraits (profiles) of the world [7-9]. N. Stukalo, M. Lytvyn, L. Golovko, L. Kolinets, Y. Pylypenko, have explored ensuring sustainable development in the world's countries based on environmental marketing [10]. M. Lytvyn has investigated the prospective scenarios for achieving sustainable development in the conditions of global challenges [11].

The Sustainable Development Report analyzes the country's position on achieving the global goals of sustainable development. The Report assesses the achievements of sustainable countries at different levels of development in the context of globalization. [1213]. 11 countries of the world are committed to achieving the 17 Global Sustainable Development Goals and the underlying 169 targets by 2030.[12]. It should be noted that the actions of different countries of the world can both positively and negatively affect the ability of other countries to achieve sustainable development goals. For example, rising seas threaten to submerge many countries and coastal communities unless all countries curb greenhouse gas emissions. (Hugo V. [14]; Lustgarten A. [15]). The operation of offshore banking centers, tax havens leads to reducing the ability of other countries to use government funding mechanisms for sustainable development. [16-17]. The use of global instruments for financing sustainable development, especially international assistance, is particularly important for achieving the global goals of sustainable development for countries with low levels of development [6,12].

However, despite the considerable number of researches, the methodological approach of the definition of the country's sustainable development in conditions of global threats remains understudied. The problems associated with the definition of the country's sustainable development in conditions of global threats are far from being solved and require further theoretical and experimental efforts. So, the purpose of the article is to form a methodological approach to define the country's sustainable development in conditions of global threats. 


\section{Method}

In the article, we have determined the new methodological approach of defining the country's sustainable development in conditions of global threats. The methodological approach allows assessing the country's sustainable development considering global threats, indicators of readiness, and vulnerability to the crisis, which, in turn, policy adjustments to strengthen sustainable development in global crises.

The methods used in this study are the statistical analysis - in quantifying the global threats of sustainable development of the world, a systematic approach - in creating the mechanism of ensuring the sustainable development of the world in conditions of global challenges, induction, and deduction - in justifying and developing a methodological approach of the definition the country's sustainable development in conditions of global threats.

\section{Results and discussion}

The achievement of the country's sustainable development in the face of global challenges is becoming increasingly important. The sustainable development is the coordinated development of the economic, environment and social processes. The systematic balancing of these three components is such a difficult task [18]. The World Sustainable Development Data Center has developed the theoretical approach to sustainable development analysis. The theoretical approach is to generalize economic, social and environmental models. [7-9]. According to this approach, the quality and security of human life characterize the process of achieving sustainable development. The sustainable development index and the security of human life are used to analyze the impact of global problems on the achievement of sustainable development in different countries of the world in the context of globalization [7]. The methodology for calculating the sustainable development index (ISD) and its components are substantiated in previous studies [8].

Let us consider the mechanism of ensuring the world's sustainable development in conditions of global challenges (Fig. 1). The process of globalization causes various changes. The positive or negative vector of these changes depends on the country's sustainable development and the country's position in the world economy. It has determined that globalization's level of impact depends on the country's sustainable development level. The higher the country's sustainable development indicators, the more positive effects of globalization the state receives. 


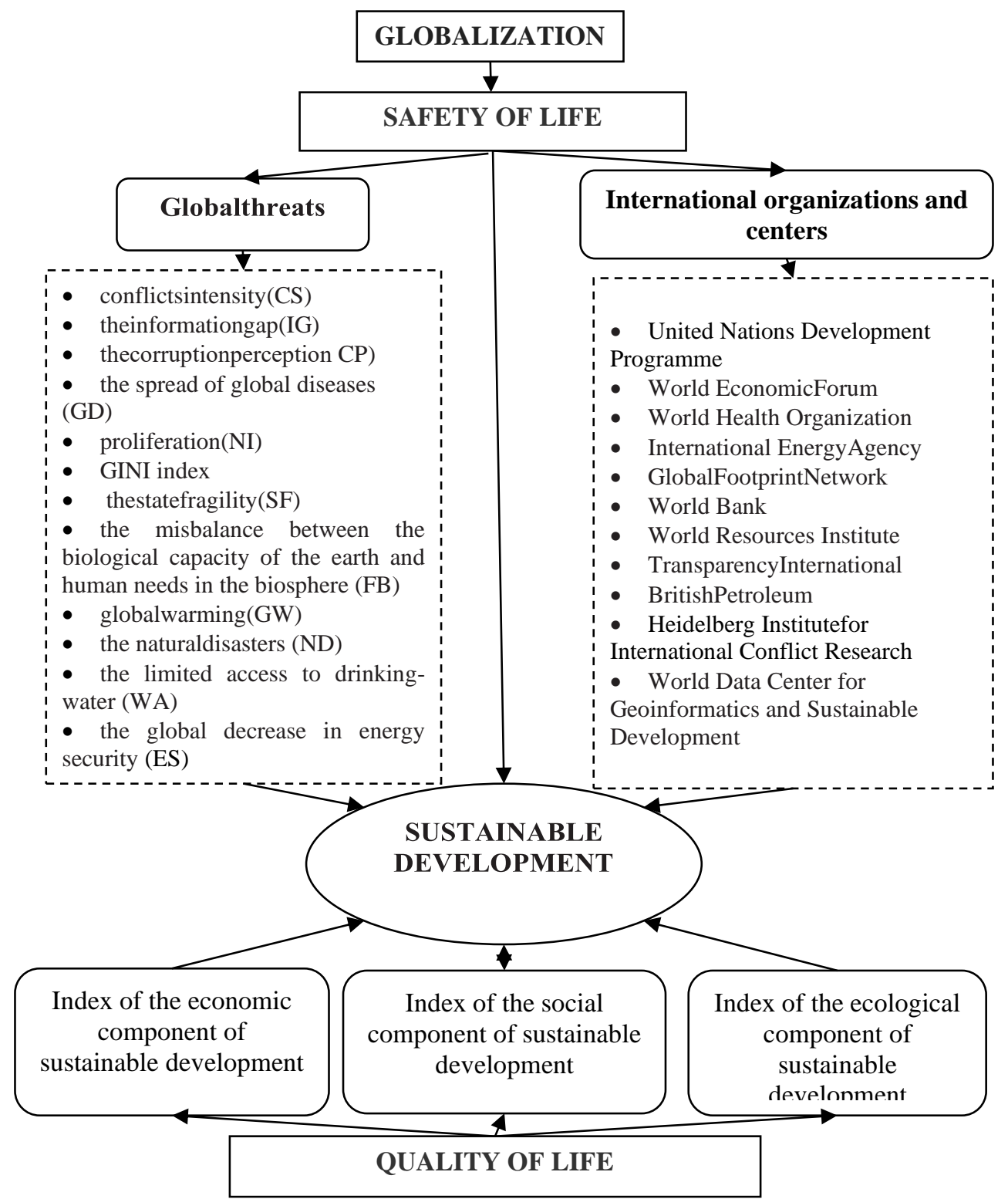

Fig. 1.The mechanism ensuring the sustainable development of the world in conditions of global challenges

Source: Author's Analysis, 2020

The adverse effects of globalization are manifested in the emergence of global crises and global threats. The international organizations, institutes and centers, such as the World Economic Forum, United Nations Development Program, Global Footprint Network, World Data Center for Geoinformatics and Sustainable Development World Resources Institute, World Bank have identified the global threats of sustainable development [8]. The social, economic, and environmental spheres are the main components of the population's life 
quality. The related activities and policies provide them a stable and mutually supportive movement.

Let's analyze the global threats of sustainable development, which have identified by the international organizations, institutions and centers [7-9]. Fig. 2 demonstrates the global threats of sustainable development for countries with the highest level of national security [8]. Finland, Canada, Australia, Germany, Norway, Sweden, Netherlands, Denmark, Switzerland, Japan have the highest index of sustainable development and the lowest level of global threats.

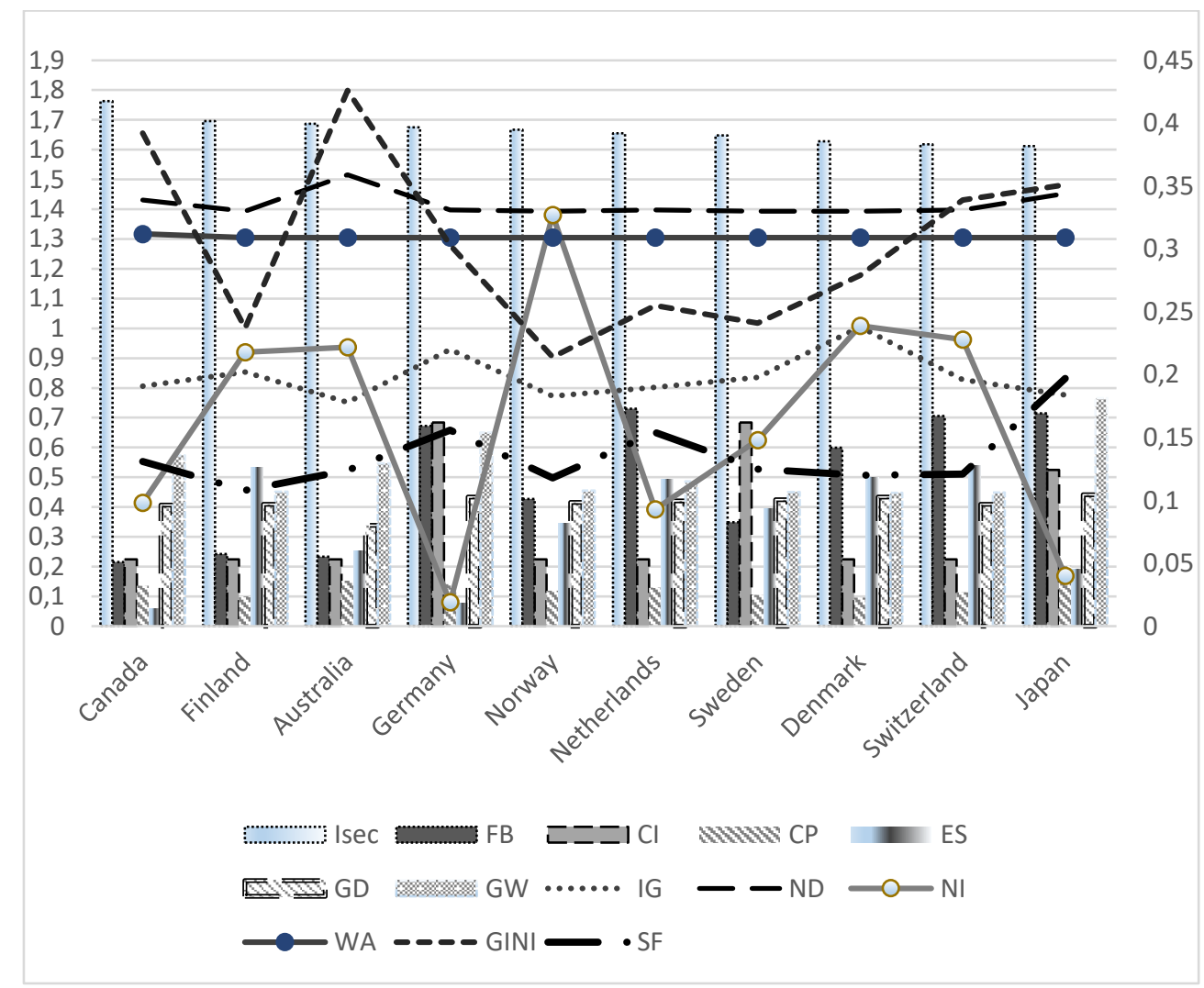

Fig. 2. The global threats of sustainable development for countries with the highest level of national security [7-9]

According to the theoretical approach, it is possible to analyze global threats to different countries and groups of countries. We have identified the impact of the global threats on large groups of countries (civilizations) united by standard cultural features [8-9]. The energy security, unemployment, inflation, currency devaluation and social problems are the main economic and social threats to achieving sustainable development in different countries of the world at the national level [2].

N. Stukalo et al. have considered that «today, the marketing of sustainable development is used actively by the G7 countries. Big companies embody the principles and standards of eco not so much to improve their image as to make "sustainable" a significant component of their long-term strategy, considering this direction as a real source of competitive advantage» [10].

The global challenge of 2020 was the COVID-19 pandemic, which led to the crisis of human development. The human development crisis is having a significant impact on 
education, human health, and economic income (the largest reduction in income since the Great Depression). [19].

The United Nations has called the COVID-19 pandemic "the greatest test that we have faced since the formation of the United Nations, it is more than a health emergency". The COVID-19 pandemic is a global crisis that is affecting the sustainable development of all countries of the world [19].

L. Jackson has considered that «an absolute risk that cannot be ignored is environmental disruption, which, as the COVID-19 crisis has shown, can wreak far more economic havoc than a financial crisis. Recurring epidemics (HIV since the 1980s, SARS in 2003, H1N1 in 2009, MERS in 2011, Ebola in 2014-16) are, like climate change, essentially human-made disasters, born of poor health and sanitary standards, the abuse of natural systems, and the growing interconnectivity of a globalized world» [5].

In March 2020 the United Nations Development Program (UNDP) has presented 2 new data dashboards which demonstrate the inequality of the countries to overcome the COVID19 crisis [19]. UNDP's Dashboard 1 on Preparedness [21] presents indicators for 189 countries (the capacity of the healthcare system, the level of development, inequalities) to assess how well the country can respond to the multiple impacts of the crisis. [20]. UNDP's Dashboard 2 on Vulnerabilities[21] presents indicators that reflect countries' susceptibility to this crisis's effects. So, more than 40 percent of the world's population does not have social protection. One in four people live in poverty, despite progress in reducing poverty and achieving sustainable development goals [20]. M.Hirt M. et al.have considered that "When an escalating set of issues triggered by the next wave of the COVID-19 crisis hits you, your plan ahead team will be what keeps your sights above thefray and what helps you win the race against time. Toget ahead of the next stage of the crisis, launch yourplan-ahead teamnow" [4].

Let us consider the methodological approach to define the country's sustainable development in conditions of global threats. At the first stage of determining the country's sustainable development in the context of global threats, the indicators of the quality and the safety of the life components that create a system of the sustainable development's indicators of the world are analyzed (see Fig. 3). The quality of the life components' indicators includes the index of the economic component of sustainable development, index of the environmental component of sustainable development, index of the social component of sustainable development [8]. The analysis of life safety considers such global threats indicators as conflicts intensity, the information gap, the corruption perception, the spread of the global diseases, proliferation, GINI index, the state fragility, the global warming, the natural disasters. 


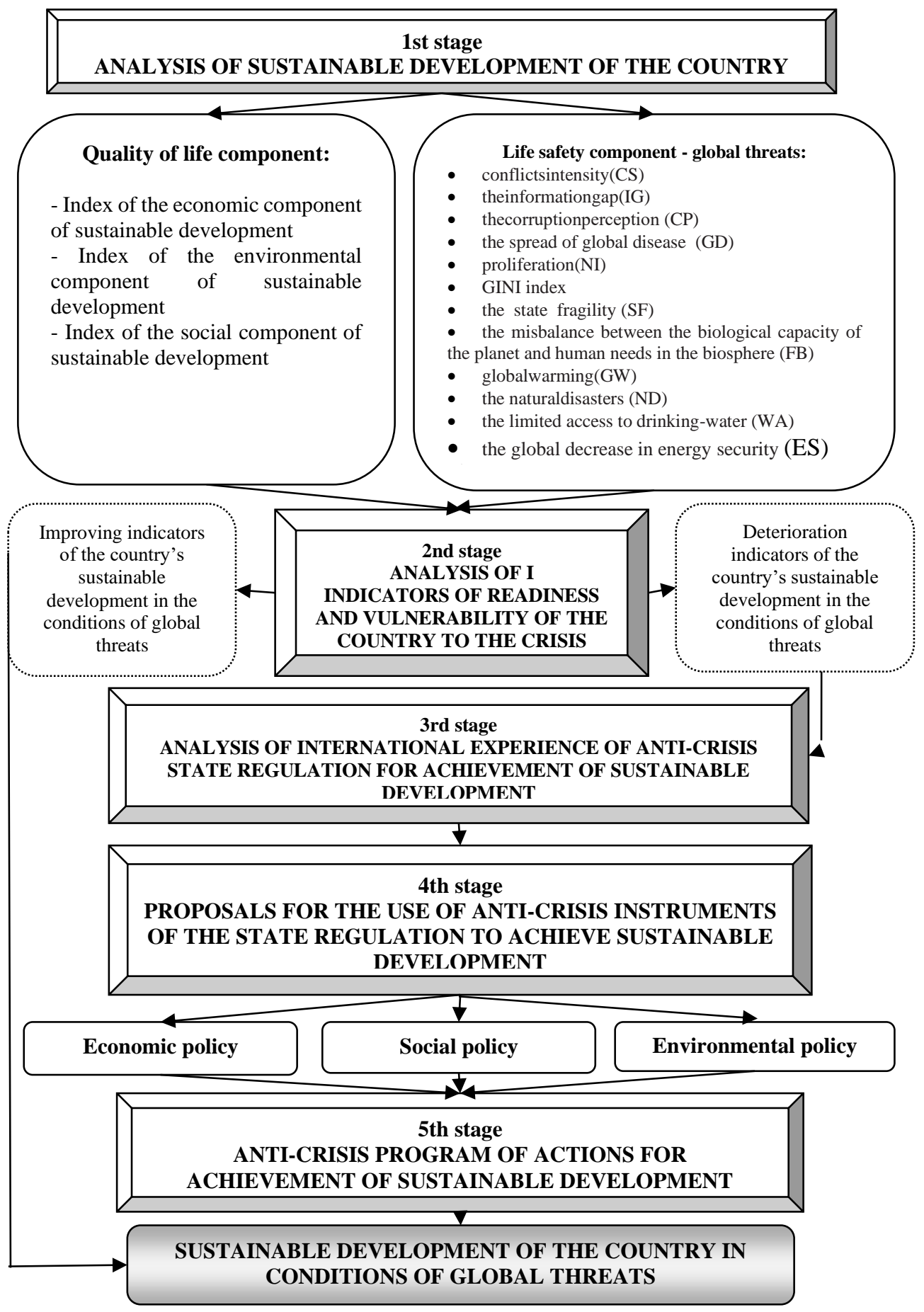

Fig. 3. The methodological approach of the definition of the country's sustainable development in conditions of global threats.

Source: Author's Analysis, 2020 
In the second stage, the country's preparedness and vulnerability indicators to the crisis have been analyzed to identify trends. Improving indicators means achieving sustainable development in the context of global threats. If there is a deterioration indicator of the country's sustainable development in the conditions of global threats, then at the third stage, the international experience of anti-crisis state regulation to achieve sustainable development is analyzed. But it is important to note that since our research shows, the relevance of implementing specific knowledge of anti-crisis measures in different countries is relative. Therefore, at this stage, it is essential not only to study but also to carefully analyze the international experience of anti-crisis state regulation to the achievement of sustainable development.

At the fourth stage, proposals to use state regulation anti-crisis instruments to achieve sustainable development of economic policy, social policy, and environmental policy are developed. At the fifth stage, an anti-crisis program of sustainable development of the country based on the considered proposals to use anti-crisis instruments of economic, social, and environmental policies is developed.

This methodological approach to define the country's sustainable development in global threats conditions allows the assessment of the country's sustainable development achievements, considering global threats, indicators of preparedness, and vulnerability to the crisis. That provides grounds for identifying anti-crisis measures adjusting policies to strengthen sustainable development in global crises [11].

\section{Conclusion}

Globalization causes various changes; the positive or negative vector of these changes largely depends on the level of sustainable development of the country and the country's position in the world economy. Authors define that the level of the impact made by globalization depends on the country's sustainable development. The higher the country's sustainable development indicators, the more positive effects of globalization the state receives. The adverse effects of globalization are manifested in the emergence of global crises and global challenges. The main components of the population's quality of life are social, economic, and environmental spheres. The related activities and policies provide them with a stable and mutually supportive movement.

At the present stage, the global challenges of sustainable development of the world economy are increasing international financial instability, conflicts intensity, the information gap, the corruption perception, the spread of global diseases, proliferation, the growing income inequality between people and countries of the planet, the state fragility, the misbalance between the biological capacity of the planet and human needs in the biosphere, the global warming, the natural disasters. The authors determine that the decline of the world economy in 2020 will be more profound than previous global crises. Still, in 2021-2022, after overcoming a new pandemic, it will begin to renew and grow following the economy's objective laws. According to the pessimistic scenario, the current global crisis can destroy the global economy's structure and reduce human development in all countries of the world. The methodological approach to defining the country's sustainable development in global threats conditions allows the assessment of the country's achievements, considering global threats, indicators of preparedness, and vulnerability to the crisis.

\section{References}

1. Z.Buryk, Theoretical and methodological basis of sustainable development economics,International Journal of Economics and Society, 6 (2),97-107 (2016) 
2. N. Stukalo, I. Steblianko, A. Simakhova, V. Doroshkevych, Trends in economic and social security at national and European level: interrelationships, threats and opportunities,Journal of Security and Sustainability Issues,8(2), 199-208 (2018)https://doi.org/10.9770/jssi.2018.8.2(7)

3. I. Zvarych, I. Ivashchuk, Inclusive growth's vectors in the functioning of the global inclusive circular economy, Perspectives - Journal on economic issues,5(1), 4-17 (2019)

4. M. Hirt, S. Smit, C. Bradley, R. Uhlaner, M. Mysore, Y. Atsmon, Getting ahead of the coronavirus crisis's next stage? (2020) https://www.mckinsey.com/businessfunctions/strategy-and-corporate-finance/our-insights/getting-ahead-of-the-next-stageof-the-coronavirus-crisis?fbclid=IwAR2ppT

1BkGRCNFp3bDiHmnWLu1tb99m9UwFwx_I_88xB v4j2vOvw0HyRmAM

5. L. Jackson, Ten worrying trends of the global economy. Here are the biggest economic challenges we face over the next ten years (2020) https://www.weforum.org/agenda/2020/05/depression-2020seconomypandemic?fbclid=IwAR3VIjh9spJQTtz7D4YPiyLXvRszUkhg0E4o319WulB QYesXSjbmGzk3U1U

6. V. Gaspar, D. Amaglobeli, M. Garcia-Escribano, D. Prady, M. Soto, Fiscal Policy and Development: Human, Social, and Physical Investment for the SDGs, International Monetary Fund Staff Discussion Note SDN/19/3 (2019)

7. M. Zgurovsky, Sustainable Development Analysis: Global and Regional Contexts, 328 (2019) http://wdc.org.ua/sites/default/files/SD2019-P1-FULL-EN.pdf

8. Foresight 2018: systemic world conflicts and global forecast for XXI century, International Council for Science, 226 (2018) http://wdc.org.ua/sites/default/files/WDCIASA-FORESIGHT-2018-EN.pdf

9. World data center for geoinformatics and sustainable development(2020) http://wdc.org.ua/en

10. N. Stukalo, M. Lytvyn, L. Golovko, L. Kolinets, Y. Pylypenko, Ensuring sustainable development in the countries of the world based on environmental marketing, Naukovyi Visnyk Natsionalnoho Hirnychoho Universytetu, 2020(3), 145-150 (2020) https://doi.org/10.33271/nvngu/2020-3/145

11. M. Lytvyn, N. Stukalo, Perspective scenarios for achieving sustainable development in the context of global threats, Economic Bulletin of the National Mining University, 2(70), 53-65 (2020), https://doi.org/10.33271/ev/70.053

12. Sustainable development report 2019. Transformations to achieve the Sustainable Development

Goals(2019)https://www.sustainabledevelopment.report/?fbclid=IwAR1br7tcmHENbf MPsS4HxoI2LDes3ed9ZZJzrLd_K8Y9z8YtVspjJglugRw

13. Sustainable Development Goals Progress Chart (2020)https://unstats.un.org/sdgs/report/2020/progress-chart 2020.pdf?fbclid=IwAR3HLcg1lbWztGjbycBfiO3IP_rZgNPiXv7G2AJ5UqlMgHGjgx 4DFxVTD

14. V. Hugo, D. Peters, M. Berg, S. Frank, P. Havlik, N. Forsell, C. Hamelinck, J. Pirker, A. Mosnier, J. Balkovič, The Land Use Change Impact of Biofuels Consumed in the EU: Quantification of Area and Greenhouse Gas Impacts, Utrecht: Ecofys (2015)

15. A. Lustgarten,Palm Oil Was Supposed to Help Save the Planet. Instead It Unleashed a Catastrophe, New York Times (2018) https://www.nytimes.com/2018/11/20/magazine/palm-oil-borneo-climate catastrophe.html.

16. IMF, International Spillovers in Corporate Taxation. IMF Policy Paper (2014) http://www.imf.org/external/np/pp/eng/2014/050914.pdf. 
17. Oxfam, Tax Battles. The dangerous global Race to the Bottom on Corporate Tax (2016)https://www.oxfam.org/en/research/tax-battles-dangerous-global-race-bottomcorporate-tax

18. D. Zerkalov,Life activity. Sustainability. Environment (2016)http://www.zerkalov.kiev.ua

19. COVID-19 and Human Development: Assessing the Crisis, Envisioning the Recovery (2020)http://hdr.undp.org/en/hdp-covid

20. COVID-19: New UNDP data dashboards reveal huge disparities among countries in ability to cope and recover (2020) https://www.ua.undp.org/content/ukraine/en/home/presscenter/pressreleases/2020/covi d-19--new-undp-data-dashboards-reveal-huge-disparities-among.html

21. Exploring vulnerabilities: COVID-19

https://datastudio.google.com/reporting/abd4128c-7d8d-4411-b49aac04ab074e69/page/CJbLB 